\title{
Commentary
}

\section{Contending the Popular: Party-State and Culture}

David S. G. Goodman

Consideration of the "popular" in the contemporary People's Republic of China (PRC) immediately confronts the methodological problem of universalism, as the essays in this issue demonstrate. The popular has certain connotations in the societies from which our analyses emanate that may or may not be commonly applied in and to contemporary Chinese society. It is, for example, often equated with both democratic and demotic developments, both of which are highly contested discourses in post-Mao China, not least because of their apparent Westernness. ${ }^{1}$ The concept of popular culture may be similarly challenged, though perhaps differently, not least since in that usage popular is more than simply an adjective, as both Li Hsiao-t'i and Jing Wang make explicit.

Academic inquiry, and particularly its language, must necessarily assume this universalism even as it dissects the popular and associated phenomena in 
order to assess whether and to what extent such assumptions might be justified. All societies are suis generis. Nonetheless, the application of generalized concepts and approaches can help characterize a society by identifying the similarities and differences against such implicit yardsticks. The end result might conceivably be a justification of this universalism, but it is perhaps more likely to identify differences that will require the amendation of concepts and theories if their general explanatory power is to be maintained.

The constant need to adjust concepts and approaches as the focus of comparison widens is particularly important at present when considering the interactions of political, economic, social, and cultural change in contemporary China. Post-Mao China has coincided with dramatic political changes internationally, especially during the last decade, that have all but universalized the project of modernization around a single model. It has become increasingly difficult to inquire, as was once extremely fashionable, about the convergent or divergent trends in the various patterns of relationships between state and society. ${ }^{2}$ Convergence is now more or less assumed as a corollary of internationalization, with debate focusing on different paths and stages of development. ${ }^{3}$ All the same the homogenizing impact of globalization may yet prove to be an overstatement, with convergence appearing either somewhat premature, or a function of the level at which generalization is attempted.

These prefatory comments are in many ways the necessary background to the question raised by some of the articles in this issue and by discussions at the workshop where they were first presented, as to the relevance of theory developed in a European context of eighteenth-and nineteenth-century social and political revolutions to China's still-Communist Party state and largely agrarian version of postsocialism. However, they also highlight some other key questions that attend the discussion of the development of contemporary popular culture, as well as some of the assumptions made in some of the descriptions of those developments. In particular, they draw attention to the changing relationships between politics and culture, and the identification of new agents of cultural change, as well as to the nature of the Chinese state's authoritarianism and the timing of its developmental process.

The post-Mao era, and even more the period since Deng Xiaoping and the Chinese Communist Party (CCP) launched themselves on their reformist 
path at the end of 1978 , has seen significant changes in the relationship between politics and culture. Necessarily, this relationship has changed in response to the CCP's adjustments to its ideology. However, at the same time writers, artists, and the producers of culture were not slow to exploit the opportunities these changes permitted, and indeed by effectively lobbying ensured increasingly greater scope for their activities. ${ }^{4}$ Perhaps the most important change was that which altered the system of political censorship from an active vetting before publication to a more passive regulation after the event. ${ }^{5}$ Particularly during the I 990 os, after Deng Xiaoping's Excursion to the South in 1992 and its provision of further direction to the reform agenda, culture became less didactic and more concerned with entertainment, more commercialized and more commercializable.

At the same time, there are also continuities in the relationship between politics and culture that cross the watersheds of both 1978 and 1992. Perhaps the most important is that the CCP has always been, and remains, concerned with popular culture. Li Hsiao-t'i's account of the emergence of a concern with "proletarian" literature during the I93os highlights the process that led the CCP to see the advantages in both using and controlling the content of popular culture. ${ }^{6}$ The yangge described by Jing Wang in her article and practiced by the elderly in Beijing during the I99os is itself already a dance form proletarianized and homogenized by the CCP for its own purposes from a series of different popular origins in North China during the I940s. ${ }^{7}$ As Li Hsiao-t'i suggests, this concern preceded Mao Zedong's address to the Yan'an Forum in May 1942. Moreover, as Jing Wang explicates, while the CCP's perspectives may have been adjusted during the last twenty years, the party's concern with the management and articulation of popular culture has not changed. Nor, for that matter, has the party closed down its internal propaganda hierarchy.

Consideration of the mechanics of the relationship between politics and culture also suggests that there are continuities as well as change. While the party-state has certainly moved from greater direct involvement in cultural affairs to greater regulation during the reform era, it would be easy to overstate its monopoly of cultural production before 1978 and to understate its involvement during the I99os. Even at the height of the Mao-dominated era of China's politics, creators of culture did not have to be previously 
state-sanctioned in order to have access to public outlets such as museums, journals, or publishing houses. Unlike in the former USSR, writers, for example, were not required to be members of the official writers' association if they wanted to be published. The initiative for writing and translation was by no means monopolized by the party-state, and, for example, George Orwell's 1984 was already available in Chinese before the reform era started, having been translated by an English-speaking freelance translator. ${ }^{8}$

In the reform era the party-state, for its part, has by no means surrendered completely its role as a creator of culture of all kinds. In part this is a qualitative argument. The electronic media-television in particular-became considerably more accessible and dominant during the ig8os, and yet they remain almost exclusively the province of the party-state. ${ }^{9}$ In the print media, the number of journals has certainly increased since the mid-r97os when every province had a literary magazine and an "art and culture" journal that mirrored the national standard-bearers. The largest growth occurred in the following ten years, and by the mid-ig8os there would have been about seven thousand such magazines. ${ }^{10}$ Certainly, too, there are now magazines and journals published outside the resources of the party-state. However, the party-state remains a significant publisher and producer of culture. The main outlets for writers, for example, remain the party-state's now much larger stable of literary magazines and its publishing houses.

The party-state's influence is also far from absent, in a number of ways, in the formation of those new agents of cultural transmission to emerge in the ig9os. The explosion of popular culture has covered a diverse range of activities, from popular religions and the popularization of religion, through the creation of new forums for popular interactions, such as private restaurants, to pop music and magazines. The commercial environment is a major stimulus, and in most cases new companies have been established to develop these activities. $^{11}$

Few of the new agents of cultural change have had no connection with the party-state. Many have worked in the party-state and taken their connections, and sometimes their training and expertise, in an appropriate activity into the nonstate sector. Particularly during the late ig8os and into the early I99os, and especially in south and east China, as the economy began to grow, many local officials found themselves losing ground economically to 
their peers. One strategy for some was to experiment in the market sector of the economy, and many (though by no means all) private restaurateurs came into their new roles in that way. Sometimes, too, economic pressures convinced officials in the party-state that with their managerial and other skills they could do better in the market. In Shanxi, the daily newspaper Life of the City is produced by a former division-level cadre in the General Office of the Taiyuan CCP Committee, and Good Friends comes from a publishing company started by journalists and officials from the Shanxi Daily.

Many, too, are the relations, often the children, of officials of the party-state who build on their and their relatives' influence to develop their enterprises. A Buddhist advisory service was developed by the son of the mayor of a district-level city, who moreover was able to establish his enterprise in a building owned by the provincial committee of the CCP. A pop music producer's father had been party secretary of a rural district. So strong and transferable are these family connections that the children themselves can forswear membership in the CCP or positions in the party-state. Having a father who had been a long-term village leader, or senior cadre, in a provincial department makes party membership unnecessary and, indeed, for cultural activists runs the possibility of being counterproductive.

However, the relationship between new cultural activities and the partystate is not just associational in those fairly obvious ways. (After all, where else would one expect well-educated, administratively competent new agents of cultural change to come from?) New cultural activities tend to have even closer structural relationships with the party-state. The party-state has not disappeared from economic interaction with society; it has simply adjusted the level at which those interactions take place. Local government now plays a central role in China's socioeconomic development. For cultural activities, as for economic enterprises, local government provides access to capital (funds, equipment, and buildings), labor, and political protection. Partly for a share of equity (and in order to generate income) and partly because it feels happier with corporatism at the local level (where it can claim a monitoring influence, particularly in the face of questions or difficulties from superior officials), local government in its turn is pressured to cooperate. The booming collective sector of the economy is largely at the level of local government 
and ensures financing and a network of influence to support activities that want to grow beyond the small scale of private enterprise.

These observations about the continued influence of the party-state would seem to confirm the arguments that suggest that the popular "from below" aspects of the drive for popular culture have been subverted "from above" in the I99os. Certainly, as Jing Wang argues in her article, the party-state has developed a new ruling technology that seems designed not to let popular culture just be. However, as always in studying the contemporary PRC as it evolves, there is a need to stand back a bit. The party-state's aims may be clear, but they, too, can be thwarted by the very social processes it seeks to manage. Social and even political groups may be complicit in their own management through an evolving corporatism, but the net result is likely to be a synthesis of their interactions with the party-state. There may be few challenges to the existence of the party-state, but there are no guarantees that its agenda will be implemented at any given time, or at least not necessarily in the way that was originally intended.

The party-state's deliberate creation of provincial and regional cultures at the end of the r 980 s and the beginning of the I99os, and their subsequent development, has been instructive in this regard. ${ }^{12}$ To encourage economic reform and local initiative, many provincial leaders purposefully encouraged the development of provincial and local cultures. Local histories and collections of local culture were published; local traditions were rediscovered and often commercialized themselves; and considerable emphasis in public rhetoric was placed on local identity and sense of place, particularly that of the province. Given the administrative origins of provinces, there was always likely to be an element of risk in this strategy. Few provinces had that kind of cultural identity beforehand. On the contrary, most provinces were administrative units intended as agents of central control. Their boundaries more usually cut across social and cultural patterns of interaction. ${ }^{13}$

Across the provinces, the results of this strategy were very mixed. In a few provinces, the strategy would have to be regarded as successful. In Shanxi, talking about a provincial culture united a number of disparate local cultures and provided a confidence previously lacking, so that its annual economic growth has regularly outpaced the national rate. ${ }^{14}$ In part the success of the cultural strategy can be attributed to the work of the republican era warlord 
Yan Xishan, who had provided a provincial consciousness absent in many other provinces. ${ }^{15}$ In part, success can also be attributed to a strategy explicitly based on recognizing the province's more local cultures and emphasizing their commonalities.

However, in more provinces the emphasis on provincial identity and local culture was less successful in achieving the aims of the party-state. In some it backfired on those provincial leaderships who had introduced such strategies, and in others it exacerbated social and political problems. In Hubei, for example, an already unpopular provincial leader managed to alienate significant social and political interests and was forced to resign. ${ }^{16}$ In Jiangxi the attempt to develop a provincial identity was always fighting a hard battle against the distinct local cultures, each of which looks more fondly to one of its four neighboring provinces than toward the collective entity. The result by the mid-I99os was an increase in the strength of these local identifications, with provincial affairs dominated by their interactions. ${ }^{17}$ In Hainan, new emphases on the province merely sought to highlight tensions among the various communities — divided by language, economic activity, and often ethnicity as well as a generation of migration — each of which claimed to be the authentic provincial voice. ${ }^{18}$

\section{Notes}

I See, for example, He Baogang, The Democratization of China (London: Routledge, I996).

2 For example, Raymond Aron, Eighteen Lectures on Industrial Society (London: Weidenfeld and Nicolson, I96r).

3 There is a vast literature on this topic, starting with G. O'Donnell, P. Schmitter, and L. Whitehead, eds., Transitions from Authoritarian Rule (Baltimore, Md.: Johns Hopkins University Press, I986). Three subsequent and significant contributions are Ellen Meiskins Wood, The Pristine Culture of Capitalism (London: Verso, I99I); Stephan Haggard and Robert R. Kaufman, The Political Economy of Democratic Transitions (Princeton, N.J.: Princeton University Press, I995); and Larry Diamond, Marc F. Plattner, Yun-han Chu, and Hung-mao Tien, eds., Consolidating the Third Wave Democracies (Baltimore, Md.: Johns Hopkins University Press, I997).

4 David S. G. Goodman, "To Write the Word for 'Man' across the Sky: Literature and Its Political Context in the People's Republic of China, I978-82," Journal of Communist Studies 1, no. 1 (March I985): 8. 
5 Hans J. Hendrischke, Populäre Lesestoffe: Propaganda und Agitation Im Buchwesen der Volksrepublik China (Bochum: Brockmeyer, I988), 328.

6 D. L. Holm, Art and Ideology in Revolutionary China (Oxford: Clarendon Press, I991).

7 On the new culture movement see Wei Hongyun, "Social Reform and Value Change in the Jin Cha Ji Border Region," in North China at War: The Social Ecology of Revolution, 1937-1945, ed. C. Feng and David S. G. Goodman (Boulder, Colo.: Rowman and Littlefield, 20oo).

8 The book was serialized in the journal Guowai zuopin xuanbian [Selections of writings from the rest of the world], published by the Foreign Languages Press, Beijing, starting with April I979.

9 This development is described in James Lull, China Turned On: Television, Reform, and Resistance (London: Routledge, I991).

Io Zhongguo tongji nianjian 1989 [China statistical yearbook] (Beijing: China Statistical Bureau, I989), 45 o.

I I Information in the following paragraphs is drawn from a study of Zhejiang and a study of Shanxi currently under way. Preliminary findings on Shanxi may be found in David S. G. Goodman, "State-Society Relations in Shanxi: Elite Interdependence and Accommodation," in Twenty Years of Reform in China, ed. Bruce Dickson (New York: M. E. Sharpe, 2000). Research on Zhejiang is reported in Goodman, "The People's Republic of China: The PartyState, Capitalist Revolution, and New Entrepreneurs," in The New Rich in Asia: Mobile Phones, McDonald's, and Middle Class Revolution, ed. R. Robison and D. S. G. Goodman (London: Routledge, I996), 225.

I2 See, for example, Hans Hendrischke, "Provinces in Competition: Region, Identity, and Cultural Construction," in The Political Economy of China's Provinces: Comparative and Competitive Advantage, ed. Hans Hendrischke and Feng Chongyi (London: Routledge, I999), r. This volume also contains specific studies of Shanxi, Jiangxi, Guizhou, and Hubei that focus on this issue.

I3 J. B. R. Whitney, China: Area, Administration, and Nation Building (Chicago: University of Chicago, Department of Geography Research Paper No.123, 1970).

I4 David S. G. Goodman, "King Coal and Secretary Hu: Shanxi's Third Modernisation," in Hendrischke and Feng, eds., Political Economy of China's Provinces, 2 I I.

I5 Donald G. Gillin, Warlord Yen Hsi-shan in Shansi Province, 191 I- 1949 (Princeton, N.J.: Princeton University Press, 1967).

I6 Zhao Lingyun, "Hubei: Rising Abruptly over Central China?” in Hendrischke and Feng, eds., Political Economy of China's Provinces, I55.

I7 Feng Chongyi, "Jinagxi in Reform: The Fear of Exclusion and the Search for a New Identity," in Hendrischke and Feng, eds., Political Economy of China's Provinces, 249.

I 8 Feng Chongyi and David S. G. Goodman, "Hainan: Communal Politics and the Struggle for Identity," in China's Provinces in Reform: Class, Community, and Political Culture, ed. David S. G. Goodman (London: Routledge, I997), 53. 
Commentary

Government from Below:

\section{The State, the Popular, and the Illusion of Autonomy}

Ralph A. Litzinger

To write a history of the culture of the popular classes exclusively from inside those classes, without understanding the ways in which they are constantly held in relation with the institutions of dominant cultural production, is not to live in the twentieth century-Stuart Hall

In his seminal essay "Notes on Deconstructing the 'Popular,'" Stuart Hall argued that the study of popular culture should always begin with what he termed "the double movement of containment and resistance." Hall reminds us that throughout the long transition from agrarian to industrial capitalism, there was a continuous struggle over the languages, traditions, 
Editorial Collective

Ann Anagnost

Charles Armstrong

Tani Barlow

Sandra Buckley

Kyeong-Hee Choi

Prasenjit Duara

Henry H. Em

Judith Farquhar

Norma Field

James Fujii

Yukiko Hanawa

James Hevia

Ted Huters

Marilyn Ivy

Marshall Johnson

Lydia Liu

Donald Lowe

Lisa Rofel

Naoki Sakai

Gi-Wook Shin

Miriam Silverberg

Mariko Tamanoi

John Treat

ling Wang

Ken Wells

Mayfair Yang

Maytair Yang

\section{Advisory Board}

Arjun Appadurai

Dipesh Chakrabarty

Kuan-Hsing Chen

Choe Jang lip

Gail Hershatter

Robert Hymes

Elaine H. Kim

Elaine H. Kim

Kojin Karatani

Mary Layoun

Mary Layoun

Lee Hyo-c

LiTwo

Lisa Lowe

Lisa Lowe
Hy van Luong

Hy van Luong

Tessa Morris-Suzuki

Aihwa Ong

Paik Nak-chung

Vince Rafael

Wark Selden

Wada Haruki
Sylvia Yanagisako

Sylvia Yanagisako
Marilyn Young

\section{Editorial Staff}

Tani Barlow, senior editor

Chungmoo Choi, associate editor

lames Hevia, associate editor

Donald Lowe, associate editor

Tamiko Nimura, managing editorial assistant

\section{Corresponding Editors}

Paik Nak-chung, Ch'angjakkwa bip'yöng (Korea)

Russell C. Leong, Amerasia Journal (USA)

Huang Ping, Wang Hui, Dushu (People's Republic of China)

Li Tuo, Chen Yangu, Horizons (People's Republic of China)

Akio Igarashi, Journal of PacificAsia (Japan)

Editorial collective, Taiwan: A Radical Quarterly in Social Studies (Taiwan)

\section{Statement of Purpose}

positions: east asiz cultures critique offers a new forum of debate for all concerned with the social, intellectual, and political events unfolding in East Asia and within the Asian diaspora. Profound political changes and intensifying global flows of labor and capital in the late twentieth century are rapidly redrawing national and regional borders. These transformations compel us to rethink our priorities in scholarship, teaching, and criticism.

Mindful of the dissolution of the discursive binary East and West, positions advocates placing cultural critique at the center of historical and theoretical practice. The global forces that are reconfiguring our world continue to sustain formulations of nation, gender, class, and ethnicity. We propose to call into question those still-pressing, yet unstable, categories by crossing academic boundaries and rethinking the terms of our analysis. These efforts, we hope, will contribute toward informed discussion both in and outside the academy.

positions' central premise is that criticism must always be self-critical. Critique of another social order must be as self-aware as commentary on our own. Likewise, we seek critical practices that reflect on the politics of knowing and that connect our scholarship to the struggles of those whom we study. All these endeavors require that we account for positions as places, contexts, power relations, and links between knowledge and knowers as actors in existing social institutions. In seeking to explore how theoretical practices are linked across national and ethnic divides, we hope to construct other positions from which to imagine political affinities across the many dimensions of our differences. positions is an independent refereed journal. Its direction is taken at the initiative of its editorial collective as well as through encouragement from its readers and writers.

\section{positions east asia cultures critique}

chinese popular culture and the state 


\section{Contributors}

Tani E. Barlow, sentor editor of positions, is the author of The Question of Women in Chinese Feminism (forthcoming).

Dai Jinhua is a professor of Chinese literature at Peking University. She is the codirector of the Luce Project of Contemporary Chinese Popular Culture and the author of Cinema and Desire (forthoming).

Judith Forquhar, a member of the positions editorial collective, is professor of anthropology at the University of North Carolina at Chapel Hill. Her new book, Appetites: Food and Sex in Poit-Socialist Chima, is forthcoming.

David S. G. Goodmon is director of the Institute for International Studies at the Institute of Technology, Sydney, Australia. His most recent work is Social and Political Change in Revolutionary China (2000).

James L. Hevia, a member of the positions editorial collective, is chair of the Curriculum in International Studies at the University of North Carolina at Chapel Hill. His book, Making China "Perfectly" Equal": The Qing Empire and the Powers, 1860-1901, is forthcoming. 


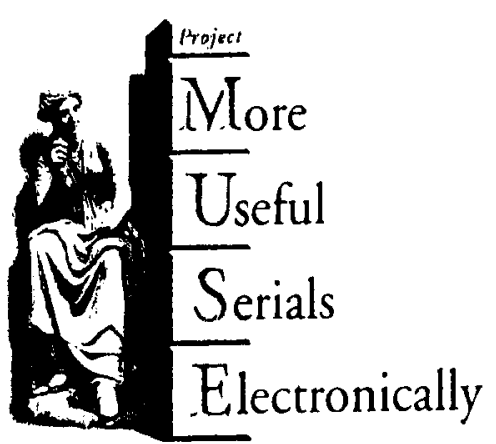

\section{Building a bigger, better MusE}

Broject MUse ${ }^{\oplus}$ now indudes scholarly journals from eleven university presses Building on the original 47 scholarly tirles offered by Johns Hopkins, the MUSE collecrion now offers 113 full-ext journals online. By merging these cilles into a single darabase, Must provides scholars with the critical content they need, com bined with all of the benefits of electronic subscriptions, including full-text and feld searching, easy navigation, and full campus availability 24 hours a day. With ous expanded list, faster servers and increased searching oprions, your users will find research has never been easier. And as a librarian, theré' no berter value for your dollar-the list price of $\$ 8,000$ is much less than the cost of subscribing to these titles in print. Our Hexible subscription options include discipline-oriented packages and single-ritle ordering to best meet your collection development needs. Substantial discounts are also offered for consortium, smaller and specia libraries. Contact us now ro see why there's more to MUSE than ever before.

Now Muse includes journals from:

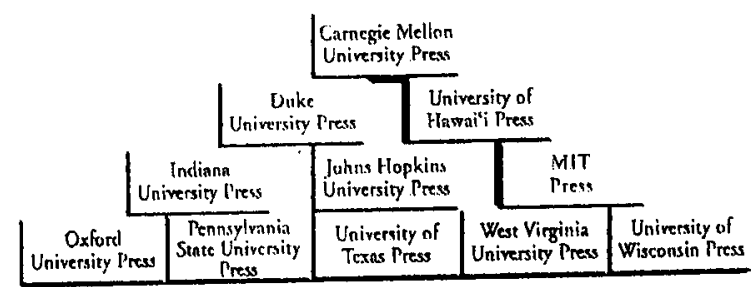

\section{Project Muse}

Setting the standard for scholarly electronic journals in the humanities and social sciences.

httip://muse.jhu.edu

Preview the expanded Project MUSE now.

Contact us for your free trial subscription at muse muse.jhu.edu or $1-800-548-1784$

\section{Submissions}

Manuscripts, letters concerning editorial matters, and bonks for review should be addressed to Tani Barlow, Senior Editor, positions: east asia cultures critique, Box $353^{6} 5^{\circ}$, University of Washington, Seattle, WA 98 195; e-mail: position $@$ u.washington.edu; Web site: http://depts. washington.edu/position/. All manuscripts must be typed and double-spaced, including quotations and endnotes, and blinded throughout. All manuscripts must be submitted in triplicate. A style guide for authors is available through the Web site or by request.

Subscriptions

All orders should be directed to Duke University Press, Journals Fulfillment, Box 9066o, Durham, NC 27708-0660. Yearly subscription rates (3 issues): students, \$19; individuals, \$29; libraries and institutions, $\$ 90$. Single-issue price: individuals, $\$ 12$; libraries and institutions, $\$ 30$. All back volumes, $\$ 90$. Add $\$ 12$ for postage outside the U.S.; Canadian subscribers add $7 \%$ GST. For more information, please contact the Duke Press Journals Division at 1-888 $387-5687$ (toll-free in the U.S.) or at 919-687-3602. An electronic subscription to the journal may be purchased from Project Muse at www.muse.jhu.edu.

Abstracts

positions is abstracted in Sociologicul .tbstracts and indexed in Arts and Humanities Citation Index, Current Contents, and Arts and Humanities Research Alert.

Photocopying

Photocopies for course or research use that are supplied to the end-user at no cost inay be made withour need for explicit permission or fee. Photocopies that are to be provided to the end-user for a photocopying fee may not be made without payment of permission fees to Duke University Press, at $\$ 2$ for each article copied.

Permissions

Requests for permission to republish copyrighted material from the journal should be addressed to Permissions Editor, Duke University Press, Box go66o, Durham, NC 277080660 .

Acknowledgment

positions is supported, in part, by the University of Washington and by the Foundation for Asian Cultural Studies.

Volume 9, Number i, Spring 2001

Copyright $\bigcirc 2001$ by Duke University Press

ISSN $1067-9847$ 


\section{positions \\ east asia cultures critique}

\section{statement of purpose}

positions: east asia cultures critique offers a new forum of debate for all concerned with the social, intellectual, and political events unfolding in East Asia and within the Asian diaspora. Profound political changes and intensifying global flows of labor and capital in the late twentieth century are rapidly redrawing national and regional borders. These transformations compel us to rethink our priorities in scholarship, teaching, and criticism.

Mindful of the dissolution of the discursive binary East and West, positions advocates placing cultural critique at the center of historical and theoretical practice. The global forces that are reconfiguring our world continue to sustain formulations of nation, gender, class, and ethnicity. We propose to call into question those still-pressing, yet unstable categories by crossing academic boundaries and rethinking the terms of our analysis. These efforts, we hope, will contribute toward informed discussion both in and outside the academy.

positions central premise is that criticism must always be self-critical. Critique of another social order must be as self-aware as commentary on our own. Likewise, we seek critical practices that reflect on the politics of knowing and that connect our scholarship to the struggles of those whom we study. All these endeavors require that we account for positions as places, contexts, power relations, and links between knowledge and knowers as actors in existing social institutions. In seeking to explore how theoretical practices are linked across national and ethnic divides, we hope to construct other positions from which to imagine political affinities across the many dimensions of our differences. pesitions is an independent refereed journal. Its direction is taken at the initiative of its editorial collective as well as through encouragement from its readers and writers.

Return to positions main page 
Copyright $(\mathcal{C}$ INSTICC - Institute for Systems and Technologies of Information, Control and Communication

All rights reserved

'Edited by'Chi-Sheng Chen, Joaquim Filipe, Isabel Seruca and José Cordeiro

Printed in Portugal

ISBN: 972-8865-19-8

http://www.iceis.org

secretariat@iceis.org 